\title{
Vegetative Growth and Yield Potential of Cauliflower (Brassica oleraceae var. botrytis, L.) Plants as Affected by Inorganic and Organic Nitrogen Fertilization
}

\author{
Abdel-Razzak, H. S ${ }^{1}$ and A. B. El-Nasharty ${ }^{2}$
}

\begin{abstract}
Two field experiments were conducted at the Experimental Station Farm, Faculty of Agriculture, Alexandria University in two successive winter seasons of $2006 / 2007$ and $2007 / 2008$ to follow up the influences of different levels of inorganic $N\left(0,40,80\right.$ and $120 \mathrm{~kg} N$ fad. ${ }^{-1}$ as $\left.\mathrm{NH}_{4} \mathrm{NO}_{3}\right)$ and organic $\mathrm{N}\left(0,5,10\right.$ and $15 \mathrm{~m}^{3}$ fad. $^{-1}$ as chicken manure), as well as their collaborative effects on cauliflower vegetative growth characters and chemical composition of leaves. In addition, determine both maximum (total and marketable yields), and minimum (non-marketable one) of cauliflower "Amshiry" cultivar were considered.

The results showed that the application of medium and high levels of inorganic $N$ fertilizer $(80$ and $120 \mathrm{~kg} \mathrm{~N}$ fad. ${ }^{-1}$ ) increased significantly most of the vegetative growth characters such as plant fresh weight, plant height, leaves number, leaves and stem dry matter content, and stem diameter. Increasing significant values for both total and marketable yield of cauliflower were, also, recorded for the same two levels. On the other hand, the non-marketable yield reflected pronounced decrease as a result of application the same two levels. Significant increases of macro- and micro-nutrient concentrations in leaves of cauliflower were obtained by raising $\mathrm{N}$ levels.

Application of chicken manure rates up to $15 \mathrm{~m}^{3}$ fad.-1 revealed significant increases in vegetative growth parameters, concentrations of macro- and micro-nutrient in leaves, and yield characters during both seasons.

The best treatment combination appeared to be that of the highest levels of inorganic and organic $\mathbf{N}$ fertilizers $\left(120 \mathrm{~kg} \mathrm{~N} /\right.$ fed. $^{-1}$ as $\mathrm{NH}_{4} \mathrm{NO}_{3}+15 \mathrm{~m}^{3}$; i.e., $72 \mathrm{~kg} \mathrm{~N} / \mathrm{fed} .^{-1}$ of chicken manure) followed by $\left(80 \mathrm{~kg} \mathrm{~N} / \mathrm{fed}^{-1}, \mathrm{NH}_{4} \mathrm{NO}_{3}+15\right.$ $\mathrm{m}^{3}$, chicken manure). Application of the last treatment gave maximum marketable yield as well as total yield, and at the same time lowered non-marketable yield of cauliflower. It can be concluded that the use of chicken manure can decrease the used quantity of inorganic $\mathbf{N}$ fertilizer and, consequently, improves the economics of cauliflower production as well as reduces the unfavorable effects on the environment under the study region conditions.
\end{abstract}

Key words: Cauliflower, chicken manure, inorganic $\mathrm{N}$, leaves nutrient contents, marketable yield, loose and buttoned curds.

\section{INTRODUCTION}

Cauliflower (Brassica oleraceae var. botrytis, L.) is a cool season vegetable crop grown for its white curds. It is represents the aristocrat of the Cruciferae family because of its delicate growing requirements and needs more attention than cabbage, broccoli and its close cruciferous relative's species (Splittstoesser, 1990).

Cauliflower being highly exhaustive crop with regard to plant nutrient where fairly large amounts of nutrients, particularly $\mathrm{N}$ is required to achieve optimum vegetative growth and maximum yield (Markovic and Djurovka, 1990 and Thompson et al., 2000). For better growth, maximum yield with good curds quality, the application of nutrients through inorganic fertilizers to cauliflower is considered a very costly. Moreover, continuous application of $\mathrm{N}$ inorganic fertilizers in intensive cropping system can build up toxic concentrations of salts in the soil, thus leading to nutritional imbalances in soil, which has an adverse effect on soil structure and health. It is believed that it can stimulate certain problems related crop diseases, insect infestations and spread of weed species, (Sherif and El-Naggar, 2005, Badawy et al., 2007, Kumar et al., 2007 and Shaheen et al., 2007).

Recently, the world goes on using different sources of organic fertilizers to replace all or reduce part of the applied amounts of inorganic fertilizers that required for plant growth. Application of organic manures to the soil whether alone or in a collaborative with mineral fertilizers has been a successful practice to build up soil humus and beneficial microbes besides, improving the soil physical and chemical properties that can get better for the root environment, stimulate plant growth and increase yield productivity (Fattah-Allah et al., 1997, Rizk et al., 2006 and Kumar et al., 2007).

Mostly, all organic manures can improve the availability of several elements in the soil through their active groups which have the ability to retain the elements in a complex or chelate forms and consequently improve the plant growth and yield both quantitatively and qualitatively (Badawy et al., 2007). Hence, the current tendency is to explore the possibility of supplementing inorganic $\mathrm{N}$ fertilizers with organic

\footnotetext{
1Vegetable Crops Dept., Fac. Agriculture, Alexandria Univ., Egypt.

${ }^{2}$ Fertilization Technology Dept., National Research Centre, Dokki,

Cairo, Egypt.

Received December22, 2008, Accepted December 31, 2008
} 
manures to sustain the plant growth and yield production. However, the shortage information regarding determine the proper application of both organic and inorganic fertilizers together and their effects on vegetables growth, yield and quality, soil fertility and environmental aspects still requires more investigations (Giardini et al., 1992 and Hasanin, 2007). From this point of view, present work was planned to investigate the efficiency of using chicken manure in conjunction with inorganic $\mathrm{N}$ fertilizer on the vegetative growth characters, leaf chemical analysis and determine the maximum total and related marketable curds yield of cauliflower "Amshiry" cultivar.

\section{MATERIALS AND METHODS}

\section{Experimental site:}

Two field experiments were carried out through two successive winter seasons of 2006/2007 and 2007/2008 at the Agricultural Experimental Station Farm, Faculty of Agriculture, Alexandria University to investigate the influences of inorganic $\mathrm{N}$ fertilizer, chicken manure and their interactions on the vegetative growth, nutrients status of leaves and yield potential of cauliflower plants "Amshiry" cultivar.

Pre-cropping soil samples of both experimental sites were collected randomly from $0-30 \mathrm{~cm}$ soil depth, to represent the experimental soil field treatments after soil preparation and before adding fertilizers. Samples of soil and chicken manure were air dried, crushed by wooden hammer, sieved through $2 \mathrm{~mm}$ sieve, thoroughly mixed and placed in polyethylene bags for physical and chemical analysis (Chapman and Pratt, 1978). Some of the main physical and chemical characteristics of both soil and chicken manure are shown in Tables 1 and 2, respectively.

\section{Inorganic $\mathbf{N}$ fertilizer source and application method:}

Ammonium nitrate $\left(\mathrm{NH}_{4} \mathrm{NO}_{3}, 33.5 \% \mathrm{~N}\right)$ fertilizer was used at rates of $\left(0,40,80\right.$ and $120 \mathrm{~kg} \mathrm{~N}$ fad. $\left.{ }^{-1}\right)$. Each $\mathrm{N}$ treatment was divided into three equal doses. The first dose was applied three weeks after planting.
The second dose was applied four weeks after the first one and the third dose was applied 20 days later as shown in Table 3 . Inorganic $\mathrm{N}$ fertilizer was surface broadcasted manually, and then $\mathrm{N}$ treatments were irrigated immediately. Before planting calcium supper phosphate $\left(15.5 \% \mathrm{P}_{2} \mathrm{O}_{5}\right)$ fertilizer was applied to the soil at a rate of $100 \mathrm{~kg} \mathrm{fad} .^{-1}$ and potassium sulphate $(48.0 \%$ $\mathrm{K}_{2} \mathrm{O}$ ) at a rate of $100 \mathrm{~kg}$ fad..$^{-1}$ was also applied to the experimental soil. Phosphate fertilizer was applied as a basal dose during soil preparation; whereas, potassium fertilizer was divided into two equal doses, half quantity was applied as a basal dose and the other half was applied after one month from transplanting.

\section{Chicken manure source and rates:}

Chicken manure was obtained from the Experimental Poultry Station, Abies region, Faculty of Agriculture, Alexandria University. It was added at three rates $\left(5,10\right.$ and $15 \mathrm{~m}^{3}$ fad. $\left.^{-1}\right)$ in addition, to control treatment (without application of chicken manure). These three additions represent 24,48 and $72 \mathrm{~kg} \mathrm{~N}$ fad. ${ }^{-1}$ and were incorporated into the surface soil layer $(0-20$ $\mathrm{cm}$ ) one week before planting (Table 3).

\section{Experimental design}

A split-plot system in a randomized complete blocks design (R.C.B.D.) with three replicates was used. Each replicate consisted of sixteen treatments representing the whole combinations among the four levels of inorganic $\mathrm{N}$ fertilizer and four rates of chicken manure as well as their interaction. The four levels of inorganic $\mathrm{N}$ fertilizer were allocated to the main plots, while, the four rates of chicken manure were randomly assigned to the sub-plots. Each sub-plot consisted of four rows $4.0 \mathrm{~m}$ length and 75 $\mathrm{cm}$ width and the plot area was $12 \mathrm{~m}^{2}$. Guard rows were set between the experimental units, left without planting to separate each two adjacent sub-plots.

Five weeks old seedlings of healthy "Amshiry" cultivar cauliflower were transplanted on one side of the ridge at a distance of $50 \mathrm{~cm}$ on Nov. $22^{\text {nd }}$ and $26^{\text {th }}$ in 2006 and 2007 seasons, respectively (Table 3).

Table 1. The main physical and chemical properties of the experimental soils prior to $\mathbf{N}$ fertilizers application

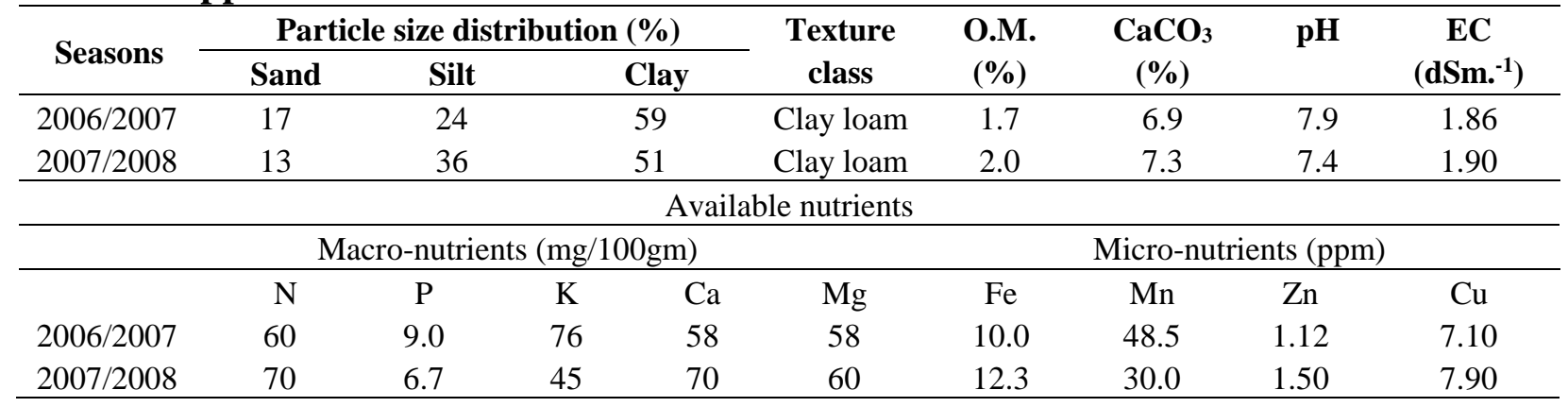


Abdel-Razzak, H. S and A. B. El-Nasharty: Vegetative Growth and Yield Potential of Cauliflower (Brassica oleraceae var. botrytis, L.) ... 327

Table 2. The main chemical characteristics of the chicken manure used

\begin{tabular}{|c|c|c|}
\hline \multirow{2}{*}{ Characteristic } & \multicolumn{2}{|c|}{ Season } \\
\hline & $2006 / 2007$ & $2007 / 2008$ \\
\hline Moisture content (\%) & 47 & 45 \\
\hline Weight $1 \mathrm{~m}^{3}$ of manure $(\mathrm{Kg})$ & 374 & 400 \\
\hline Organic matter $(\%)$ & 33.9 & 31.5 \\
\hline Organic carbon $(\%)$ & 19.7 & 18.3 \\
\hline Nitrogen $(\%)$ & 1.3 & 1.2 \\
\hline $\mathrm{C} / \mathrm{N}$ ratio & $15: 1$ & $15: 1$ \\
\hline a $\mathrm{pH}$ & 7.6 & 8.0 \\
\hline a Total dissolved salts (\%) & 0.47 & 0.38 \\
\hline \multicolumn{3}{|c|}{${ }^{\mathrm{a}}$ Macro-nutrients (\%) } \\
\hline${ }^{\mathrm{b}} \mathrm{P}$ & 0.12 & 0.17 \\
\hline $\mathrm{K}$ & 1.80 & 1.50 \\
\hline $\mathrm{Ca}$ & 0.44 & 0.80 \\
\hline $\mathrm{Mg}$ & 0.14 & 0.17 \\
\hline \multicolumn{3}{|c|}{${ }^{\mathrm{a}}$ Micro-nutrients (ppm) } \\
\hline $\mathrm{Fe}$ & 60.70 & 40.90 \\
\hline $\mathrm{Mn}$ & 6.10 & 9.00 \\
\hline $\mathrm{Zn}$ & 18.50 & 20.00 \\
\hline $\mathrm{Cu}$ & 36.50 & 30.50 \\
\hline
\end{tabular}

a $(1: 10 \mathrm{w}: \mathrm{v})$ chicken manure : water extract.

b Total P content was determined using wet digestion (Isamu, 1972).

Table 3. Dates of chicken manure application, transplanting, levels of inorganic $\mathbf{N}$ application, first and last harvesting for cauliflower "Amshiry"cultivar during two winter seasons of 2006/2007 and 2007/2008

\begin{tabular}{|c|c|c|c|c|c|c|c|c|c|}
\hline \multirow[t]{2}{*}{$\begin{array}{c}\text { Planting } \\
\text { seasons }\end{array}$} & \multirow{2}{*}{\multicolumn{2}{|c|}{$\begin{array}{l}\text { Date and rate of } \\
\text { chicken manure } \\
\text { application fad. }{ }^{-1}\end{array}$}} & \multirow[t]{2}{*}{$\begin{array}{c}\text { Transplanting } \\
\text { date }\end{array}$} & \multirow{2}{*}{$\begin{array}{c}\text { Levels of } \\
\text { inorganic } \mathrm{N} \\
\left(\mathrm{kg} \mathrm{N}^{\mathrm{N}} \text { fad. }^{-1}\right)\end{array}$} & \multicolumn{3}{|c|}{$\begin{array}{c}\text { Dates of inorganic } \mathbf{N} \\
\text { applications }\end{array}$} & \multirow[t]{2}{*}{$\begin{array}{c}\text { First } \\
\text { harvest }\end{array}$} & \multirow[t]{2}{*}{$\begin{array}{c}\text { Last } \\
\text { harvest }\end{array}$} \\
\hline & & & & & First & Second & Third & & \\
\hline \multirow{6}{*}{$2006 / 2007$} & & 17 Nov. & & & 10 & 11 & 2 & \multirow{6}{*}{$\begin{array}{c}26 \\
\text { Feb. }\end{array}$} & \multirow{6}{*}{$\begin{array}{l}29 \\
\text { Mar. }\end{array}$} \\
\hline & $\left(\mathrm{m}^{3}\right)$ & $(\mathrm{kg} \mathrm{N})$ & & & Dec. & Jan. & Feb. & & \\
\hline & 00 & 00.00 & & 00 & 00 & 00 & 00 & & \\
\hline & 05 & 24.31 & 22 Nov. & 40 & 13.33 & 13.33 & 13.33 & & \\
\hline & 10 & 48.62 & & 80 & 26.67 & 26.67 & 26.67 & & \\
\hline & 15 & 72.93 & & 120 & 40.00 & 40.00 & 40.00 & & \\
\hline \multirow{6}{*}{$2007 / 2008$} & & 20 Nov. & & & 19 & 18 & 10 & \multirow{6}{*}{$\begin{array}{c}5 \\
\text { Mar. }\end{array}$} & \multirow{6}{*}{$\begin{array}{c}3 \\
\text { Apr. }\end{array}$} \\
\hline & $\left(\mathrm{m}^{3}\right)$ & $(\operatorname{kg~N})$ & & & Dec. & Jan. & Feb. & & \\
\hline & 00 & 00.00 & 26 Nov. & 00 & 00 & 00 & 00 & & \\
\hline & 05 & 24.00 & & 40 & 13.33 & 13.33 & 13.33 & & \\
\hline & 10 & 48.00 & & 80 & 26.67 & 26.67 & 26.67 & & \\
\hline & 15 & 72.00 & & 120 & 40.00 & 40.00 & 40.00 & & \\
\hline
\end{tabular}

Common cultural practices were used for the cauliflower production such as irrigation, and diseases, insects and weeds control as required to maintain good crop health, according to recommended practices for cauliflower in the commercial fields.

The harvesting period was achieved from Feb., $26^{\text {th }}$ to March, $20^{\text {th }}$ in the first season and from March, $15^{\text {th }}$ to April, $12^{\text {nd }}$ in the second one (Table 3). At the end of each growing season, cauliflower plants were harvested 5-7 days intervals when heads were well-developed and firm (minimum curds diameter $\geq 20 \mathrm{~cm}$ ). Cauliflower heads were cut, trimmed to marketable form and used to determine both marketable fresh weight yield and non- marketable yield; i.e., undersized head, bolting, buttons and blindness which would not be acceptable for marketing.

Data recorded:-

\section{Vegetative growth characters:}

At harvest, the following growth attributes were quantified:-

a- Plant fresh weight (g): It was expressed as the average weight of five plant samples after cutting the plants at ground level.

b- Plant height $(\mathrm{cm})$ : It was measured from soil surface to the top of plant by using a meter. 
c- Number of leaves plant ${ }^{-1}$ : Total expanded true leaves were detached and counted.

d- Leaves weight (g): Leaves were cut to about the apex of the curd as it is customary in the preparation of cauliflower for market. It was calculated as the average weight of all detached leaves of five plants.

e- Leaves dry matter: Samples from five random detached young inner leaves were collected, washed; its weight was measured and then dried in an oven at $70^{\circ} \mathrm{C}$ to attain constant weight for determination of dry matter content.

\section{Cauliflower stems characteristics:}

After cutting the plants at ground level, five cauliflower plants were separated into wrapper leaves, rest of leaves, curds and stems. Then, five selected stems samples were used to determine the following characters:

a- Stem weight $(\mathrm{g})$ : It was recorded as the average weight of five stems.

b- Stem diameter $(\mathrm{cm})$ : It was estimated via using a caliper.

c- Stem length $(\mathrm{cm})$ : It was measured by using a meter.

d- Stems dry matter content (\%): Samples of five cauliflower stems were collected, washed, cut to small pieces to weight $30-40 \mathrm{~g}$ sample, and dried in an oven for $48 \mathrm{hr}$ at $70^{\circ} \mathrm{C}$ till the weight became constant.

\section{Determination of nutrients in the leaves:}

The youngest fully matured leaf is an actively growing plant part and considered as an excellent choice for nutrient analysis (Kubota et al., 1996). Therefore, each sample was consisted of 10 leaves (of the most recently fully expanded leaves) from five cauliflower plants which were selected from the middle row of each plot at harvest stage.

Detached leave samples were cleaned by dipping in diluted acid $(0.001 \mathrm{~N} \mathrm{HCl}$ solution) followed by rinsing with tap water and finally rinsing with three successive distilled water, dried in an oven at $70^{\circ} \mathrm{C}$ for $48 \mathrm{hr}$, ground in stainless steel mill to pass through $0.5 \mathrm{~mm}$ screen. The plant sample $(1.0 \mathrm{~g})$ was ashed in a muffle furnace at $500^{\circ} \mathrm{C}$ for $6 \mathrm{hrs}$ (Jones et al., 1991). The ash was then dissolved by adding $5 \mathrm{ml}$ concentrated mineral acids mixture (3:1 $\mathrm{HCl}: \mathrm{HNO}_{3}$ conc.). After $30 \mathrm{~min}$, vial content was quantitatively transformed using bidistilled water to $100 \mathrm{ml}$ volumetric flask, homogenized and filtered through ashless filter paper in a polythene container with sealed cover for the minerals analysis.

Determination of $\mathrm{N}$ was performed (based on the Micro-kjeldahl method) under steam distillation using Buechi-316 unit and of $\mathrm{P}$ was determined using
Spectrophotometer (Zaies) and of $\mathrm{K}, \mathrm{Ca}$, and $\mathrm{Na}$ via using Flame photometer (Jenway, PFP7) and of Mg, Fe, $\mathrm{Mn}, \mathrm{Zn}$ and $\mathrm{Cu}$ by the use of Atomic Absorption Spectrophotometer (GBC 932 AA).

\section{Total, marketable and non-marketable yields:}

Cauliflower plants were dissected to determine the following data:

a- Total yield of cauliflower plants: It was calculated as the total weight of all collected plants from each plot and converted into Ton fad. ${ }^{1}$.

b- Marketable yield: The number of marketable cauliflower plants were recorded, weighed and converted into Ton fad.- ${ }^{1}$.

c- Non-marketable yield: The number of non-marketable cauliflower plants including undersized head, bolting, buttons and blindness plants were counted, then weighed and converted into Ton fad.- ${ }^{1}$.

\section{Statistical Analysis:}

The obtained data were statistically analysis using the analysis of variance procedure following Co-Stat Software computer program for statistics (2004). Means for the two factors under consideration and their collaborative were determined and compared according to Duncan's multiple range test at a probability error of 5\% level (Steel and Torrie, 1980).

\section{RESULTS AND DISCUSSION}

\section{Vegetative growth}

\section{(A) Effects of inorganic $\mathbf{N}$ fertilizer:}

The results in Table 4 showed that increasing application of inorganic $\mathrm{N}$ fertilizer positively influenced all vegetative growth characters. Plant fresh weight, plant height, leaves number and leaves dry matter content were significantly responded to the application of medium and high levels of inorganic $\mathrm{N}$ fertilizer ( 80 and $120 \mathrm{~kg} \mathrm{~N} \mathrm{fad.} .^{-1}$ ) than other treatments. Leaves number plant ${ }^{-1}$ showed in the two seasons lesser response to the applied $\mathrm{N}$ doses of the inorganic $\mathrm{N}$ fertilizer, that might be explained on the genetically bases of this character. However, inorganic $\mathrm{N}$ fertilizer at each level increased significantly leaves weight compared with unfertilized control treatment (without addition of $\mathrm{N}$ fertilizer, soil N) in both seasons. Similar results were obtained by Farrag et al., (2000) who indicated that plant height, plant fresh weight and leaves dry matter percentage increased with increasing $\mathrm{N}$ level up to $70 \mathrm{~kg}$ $\mathrm{N}$ fad. ${ }^{-1}$. The effective response of cauliflower plants to the different levels of inorganic $\mathrm{N}$ fertilizer may be related to the $\mathrm{N}$ availability characteristics of the mineral $\mathrm{N}$ fertilizers applied. Ammonium nitrate fertilizer is water soluble, and the $\mathrm{N}$ is immediately available for uptake when the fertilizer is added to the soil 
Abdel-Razzak, H. S and A. B. El-Nasharty: Vegetative Growth and Yield Potential of Cauliflower (Brassica oleraceae var. botrytis, L.) ... 329 
(Smith and Hadley, 1988). During the vegetative growth phase, $\mathrm{N}$ is rapidly taken up from the soil and accumulated in stem and leaf tissues, where it is constituent of many enzymes necessary for assimilation and meristematic activity (Bowen et al., 1999). Accordingly, enhancing the amount of metabolites is necessary for growth and building plant organs (Marschner, 1994).

\section{(B) Effects of chicken manure:}

Chicken manure application had significant effects on all cauliflower vegetative growth characters (Table 4). The values of all parameters increased linearly with each increase of chicken manure rate. Growth characters reached their highest values with the application of the highest rate of chicken manure; $15 \mathrm{~m}^{3}$ fad. ${ }^{-1}$; i.e., $72 \mathrm{~kg}$ $\mathrm{N}$ fad. ${ }^{-1}$. In contrary, the lowest plant growth characters were produced by the lowest application rate of $5 \mathrm{~m}^{3}$ fad. $^{-1}$ and control treatment (without application of organic fertilizer) in both seasons. The highest chicken manure rate $\left(15 \mathrm{~m}^{3}\right.$ fad..$\left.^{-1}\right)$ recorded maximum values for plant fresh weight $(5.784,5.477 \mathrm{~kg})$; plant height (95.34, $90.83 \mathrm{~cm})$; leaves number $(24.15,19.69)$; leaves weight $(3.168,2.954 \mathrm{~kg})$ and leaves dry matter content $(19.43,17.30 \%)$ in both seasons, respectively. It is interesting to notice that the highest rate of organic $\mathrm{N}$ fertilizer $\left(15 \mathrm{~m}^{3}\right.$ fad. $\left.^{-1}\right)$ recorded the highest values for all vegetative growth characters under consideration more than any level of inorganic $\mathrm{N}$ fertilizer; this was true in both growing seasons. Such a superiority of chicken manure seemed to be probably due to its narrow $\mathrm{C} / \mathrm{N}$ ratio, 15:1 (Table 2) which leads to high rate of decomposition and release of sufficient nutrients to be available for growing plants (Moussa et al., 1993).

\section{(C) Collaborative effects of inorganic and organic $\mathbf{N}$ fertilizers:}

Concerning the interaction effects of inorganic $\mathrm{N}$ fertilizer and chicken manure, Table 4 showed that the highest level of inorganic $\mathrm{N}\left(120 \mathrm{~kg} \mathrm{~N}\right.$ fad. $\left.{ }^{-1}\right)$ combined with the highest rate of chicken manure $\left(15 \mathrm{~m}^{3} \mathrm{fad}^{-1}\right)$ reflected a significant effect on plant fresh weight compared with other interaction treatments in both seasons. This result can support the finding of Farag et al., (1994), who indicated that the increase of cauliflower fresh weight was corresponding to increasing $\mathrm{N}$ fertilization when supply plants grown in heavy clay soil with $0-120 \mathrm{~kg} \mathrm{~N}$ fad. ${ }^{-1}$ as $\mathrm{NH}_{4} \mathrm{NO}_{3}$. However, the highest rate of organic $\mathrm{N}\left(15 \mathrm{~m}^{3} \mathrm{fad}^{-1}\right)$ combined with any level of inorganic $\mathrm{N}$ fertilizer gave the highest values of characters plant height, leaves number, leaves weight and leaves dry matter content. Also, the highest level of inorganic $\mathrm{N}\left(120 \mathrm{~kg} \mathrm{~N}\right.$ fad..$\left.^{-1}\right)$ combined with the highest rate of chicken manure (15 $\mathrm{m}^{3}$ fad. ${ }^{-1}$ ) revealed the maximum values for the previous vegetative growth characters with the exception for leaves number and leaves weight in the first season only where the medium level of inorganic $\mathrm{N}$ fertilizer $(80 \mathrm{~kg}$ $\mathrm{N}$ fad. $^{-1}$ ) combined with the highest rate of chicken manure $\left(15 \mathrm{~m}^{3}\right.$ fad. $\left.^{-1}\right)$ was more superior than other treatment. This interaction positive effects may be due to the efficiency of inorganic $\mathrm{N}$ source $\left(\mathrm{NH}_{4} \mathrm{NO}_{3}\right)$ for the stimulating the action of chicken manure and thereby contribute more for macro and micro-nutrients supplied for the growing cauliflower plants.

\section{Cauliflower stems characteristics:}

Concerning the influences of different inorganic $\mathrm{N}$ levels, chicken manure rates and their interactions on stem weight, stem dimensions (stem length and diameter), and stem dry matter content at harvest are given in Table (5).

\section{(A) Effects of inorganic $\mathrm{N}$ fertilizer:}

Table (5) showed that inorganic $\mathrm{N}$ application had significant effects on all stem characteristics under consideration but with different trends. The highest inorganic $\mathrm{N}$ level $\left(120 \mathrm{~kg} \mathrm{~N}_{\text {fad. }}{ }^{-1}\right)$ exhibited high values for all studied stem characters with the exception of stem diameter character where, both medium and high levels of inorganic $\mathrm{N}$ fertilizer increased, significantly, stem diameter compared with other treatments. On the other hand, the differences between unfertilized treatment (control) and the medium level of inorganic $\mathrm{N}(80 \mathrm{~kg} \mathrm{~N}$ fad. ${ }^{-1}$ ) was not high enough to be significant for stem length character in both seasons of experiments. This may be referred to the applied inorganic $\mathrm{N}$ levels as well as the prevailing temperature of the experiments. Nothmann, (1976) discussed similar finding for lettuce plants on the basis that in winter season, when low temperature prevailed, stem elongation was very slow and the shot apex remained deep in the center of the head until the end of the growing period, while with relative high temperature bolting was characterized by the sudden acceleration of the rate of stem elongation. However, other cauliflower varieties can mature more uniformly on based low temperature (Wurr et al., 1981).

\section{(B) Effects of chicken manure:}

Table (5) revealed linear increase in all stem characteristics (stem weight, stem diameter, stem length and stem dry matter) as a result of using chicken manure. The maximum values were significantly recorded when cauliflower plants fertilized with the highest rate of chicken manure $\left(15 \mathrm{~m}^{3}\right.$ fad. $\left.^{-1}\right)$ in both seasons. These results could be attributed to the effect of chicken manure on the increase in the absorption of essential macro- and micro-nutrients and encourage photosynthesis process that led to more accumulation of 
metabolites in reproductive organs which in turn improve vegetative growth characters.

(C) Collaborative effects of inorganic and organic $\mathbf{N}$ fertilizers:

Table (5) showed that cauliflower fertilized with the highest level of inorganic $\mathrm{N}\left(120 \mathrm{~kg} \mathrm{~N}\right.$ fad. $\left.{ }^{-1}, \mathrm{NH}_{4} \mathrm{NO}_{3}\right)$ and the highest rate of organic $\mathrm{N}\left(15 \mathrm{~m}^{3}\right.$ fad. $^{-1}$; i.e., 72 $\mathrm{kg} \mathrm{N}$ fad. ${ }^{-1}$ of chicken manure) produced the heaviest stem weight, the thickest stem diameter, the tallest stem length and the highest stem dry matter content in the two experiments. It was also noticeable that the plots without inorganic $\mathrm{N}$ supply or non manure treatments achieved the lowest mean values of the previous characters of cauliflower stems. The favorable positive effect of the interaction between inorganic and organic $\mathrm{N}$ fertilizers on cauliflower stem characteristics was probably due to continuous release of $\mathrm{N}$ which may accumulate dry matter in stem tissues and supports the stem growth.

\section{Nutrients status in cauliflower leaves:}

\section{(A) Effects of inorganic $\mathbf{N}$ fertilizer:}

Tables 6 and 7 showed that most of the macro and micro-nutrient concentrations were linearly increased significantly in the leaves with increasing inorganic $\mathrm{N}$ levels from 40 to $120 \mathrm{~kg} \mathrm{~N}$ fad. ${ }^{-1}$. The same trend was obtained by Csizinszky, (1996), who reported that increasing $\mathrm{N}$ rates had a positive effect on the $\mathrm{N}$ and $\mathrm{Mn}$ concentrations in cauliflower leaves. Also, Sanderson and Ivany, (1999) found that leaf tissue $\mathrm{N}$ concentration was, significantly, higher at $120 \mathrm{~kg} \mathrm{~N} \mathrm{ha}^{-1}$ than $90 \mathrm{~kg} \mathrm{~N}$ $\mathrm{ha}^{-1}$ for other Brassica species including cabbage, Brussels sprouts and broccoli. On the other hand, these results are in disagreement with those of Farrag et al., (2000), who pointed out that application of inorganic N fertilizer increased whole cauliflower leaf $\mathrm{N}$ content, but $\mathrm{N}$ rates had insignificant effect. In addition, $\mathrm{P}$ content was not affected and $\mathrm{K}$ content decreased.

\section{(B) Effects of chicken manure:}

The organic $\mathrm{N}$ fertilizer exhibited similar effect to the inorganic $\mathrm{N}$ fertilizer (Tables 6 and 7), as the rate of organic $\mathrm{N}$ fertilizer increased from 5 to $15 \mathrm{~m}^{3}$ fad. $^{-1}$ the concentrations of $\mathrm{N}, \mathrm{P}, \mathrm{K}, \mathrm{Ca}, \mathrm{Mg}, \mathrm{Na}, \mathrm{Fe}, \mathrm{Mn}, \mathrm{Zn}$ and $\mathrm{Cu}$ gradually increased in the leaves of cauliflower plants. It is clear that the highest rate of chicken manure $\left(15 \mathrm{~m}^{3}\right.$ fad. $\left.^{-1}\right)$ increased significantly all nutrient concentrations than other manure treatments in both seasons of study. The results in Tables 7 and 8 also revealed superiority of the highest rate of organic N (15 $\mathrm{m}^{3}$ fad. $^{-1}$ ) than the highest level of inorganic $\mathrm{N}$ fertilizer $\left(120 \mathrm{~kg} \mathrm{~N}\right.$ fad. $\left.{ }^{-1}\right)$ in their effects on some important nutrients such as $\mathrm{N}, \mathrm{P}, \mathrm{K}$ and $\mathrm{Na}$ concentrations in cauliflower leaves in the two seasons, except for $\mathrm{K}$ and $\mathrm{Na}$ concentrations in the second one. Concerning to the superiority in some important nutrient concentrations in cauliflower leave tissues by application of the highest rate of chicken manure $\left(15 \mathrm{~m}^{3} \mathrm{fad}^{-1}\right)$, may be attributed to its high contents of $\mathrm{N}, \mathrm{P}, \mathrm{K}$ and $\mathrm{Na}$ elements. However, it was noticed decreases of $\mathrm{K}$ and $\mathrm{Na}$ contents in a chicken manure in the second season compared with the manure sample in the first one (Table 2). Such positive response for chicken manure can refer to the production of organic and inorganic acids during the degradation of such organic materials as a result of the micro-organisms activities. Both types of acids must have contributed in a decrease in soil $\mathrm{pH}$ which would reduce $\mathrm{P}$ and $\mathrm{K}$ fixation and producing more chelating ions, leading to an increase in available forms of elements in the rhizosphere zone (Helmy and Ramadan, 2008).

(C) Collaborative effects of inorganic and organic $\mathbf{N}$ fertilizers:

Regarding the interaction between different inorganic $\mathrm{N}$ levels and organic $\mathrm{N}$ rates, concentrations of $\mathrm{N}, \mathrm{K}, \mathrm{Ca}, \mathrm{Fe}, \mathrm{Mn}, \mathrm{Zn}$ and $\mathrm{Cu}$ were, significantly affected while, $\mathrm{P}, \mathrm{Mg}$ and $\mathrm{Na}$ concentrations were, insignificantly affected by collaborative treatments in the two seasons (Tables 6 and 7). High percentages of N, K, Fe, Mn, Zn and $\mathrm{Cu}$ concentrations of cauliflower leaves were recorded when plants received the highest combined levels of inorganic $\mathrm{N}\left(120 \mathrm{~kg} \mathrm{~N}\right.$ fad. $\left.{ }^{-1}\right)$ and chicken manure rate $\left(15 \mathrm{~m}^{3}\right.$ fad $\left.^{-1}\right)$. However, Ca concentration in leaves was significantly affected by combined high chicken manure rate $\left(15 \mathrm{~m}^{3}\right.$ fad..$\left.^{-1}\right)$ with any application level of inorganic $\mathrm{N}$ fertilizer in both seasons, and $\mathrm{Cu}$ concentration in the second one only.

The percentages of nutrients in cauliflower leaves during fertilization with different inorganic $\mathrm{N}$ levels and chicken manure rates are ranged from $1.18-4.37 \%$ for $\mathrm{N}$, $0.48-0.91 \%$ for $\mathrm{P}, 3.13-4.26 \%$ for $\mathrm{K}, 2.83-3.93 \%$ for $\mathrm{Ca}$, $0.10-0.23 \%$ for $\mathrm{Mg}, 56.67-108.67 \mathrm{ppm}$ for Fe, 21.00$41.67 \mathrm{ppm}$ for $\mathrm{Mn}$ and from 40.67-97.33 ppm for $\mathrm{Zn}$ (Tables 7 and 8). The relatively same trend of such nutrient concentrations in cauliflower leaves was reported in the studies of Csizinszky, (1996) and Yildirim and Guvenc, (2005) with some exceptions. Their results indicated that the concentrations of the previous nutrients ranged from $2.29-4.29 \%$ for $\mathrm{N}, 0.33-$ $0.45 \%$ for $\mathrm{P}, 2.59-3.42 \%$ for $\mathrm{K}, 0.29-0.46 \%$ for $\mathrm{Ca}$, 0.15-0.24 for $\mathrm{Mg}, 42.30-93.00 \mathrm{ppm}$ for $\mathrm{Fe}$, 45.80-61.70 ppm for Mn and from 30.90-36.60 ppm for Zn.

\section{Cauliflower total yield and quality:}

\section{(A) Effects of inorganic $\mathbf{N}$ fertilizer levels:}

Results in Table (8) showed that there were significant differences in total yield, marketable and nonmarketable yield of cauliflower plants in the two seasons 
Abdel-Razzak, H. S and A. B. El-Nasharty: Vegetative Growth and Yield Potential of Cauliflower (Brassica oleraceae var. botrytis, L.) ... 333 
Abdel-Razzak, H. S and A. B. El-Nasharty: Vegetative Growth and Yield Potential of Cauliflower (Brassica oleraceae var. botrytis, L.) ... 335

of study. The maximum total and marketable yield were produced by application high level of inorganic N (120 $\mathrm{kg} \mathrm{N}$ fad. ${ }^{-1}$ ) followed by medium level of inorganic $\mathrm{N}$ $\left(80 \mathrm{~kg} \mathrm{~N}\right.$ fad. $\left.^{-1}\right)$ without significant differences between both levels. However, the highest value of nonmarketable yield was obtained by unfertilized (control) treatment in both seasons of experiment. The percentages of increasing in both total and marketable yield obtained by the highest inorganic $\mathrm{N}$ level $(120 \mathrm{~kg}$ $\mathrm{N}$ fad. ${ }^{-1}$ ) compared with zero level (control treatment) were $11.34 \%, 8.34 \%$, and $13.93 \%, 11.02 \%$ in the first and second seasons, respectively. These findings are in agreement with those of Sanchez et al., (1996); Kubota et al., (1996); Thompson et al., (2000) and AbdelRazzak et al., (2008-b), who reported that the total and marketable yield of cauliflower curds were generally highly responsive to the rate of applied inorganic $\mathrm{N}$ in different types of soils including desert soil. Moreover, a strongly responsive cauliflower cultivar is sensitive to $\mathrm{N}$ shortage and would require a high level of fertilization, especially of $\mathrm{N}$ to assure high yield potential as indicated by Markovic and Djurovka, (1990) and Rather et al. (1999). The finding of the current study sustains the recent obtained results of Abdel-Razzak et al., (2008-b) that the total yield of cauliflower "Amshiry" cultivar increased as a result of increasing marketable yield. That is parallel to the findings of Batal et al., (1997) who mentioned that the total yield was higher because more marketable cauliflower heads were produced under the clay loam soil conditions.

On the contrary, the percentage of non-marketable curds significantly increased with limiting $\mathrm{N}$ supply, particularly, with low inorganic $\mathrm{N}$ level $\left(40 \mathrm{~kg} \mathrm{~N}_{\text {fad. }}{ }^{-1}\right)$ or with unfertilized treatment (Table 8). Non-marketable curds consisted of loose, blindness and buttoned curds. However, malformation and riceyness were not observed under this investigation conditions. This result can confirm results of Dufault and Waters, (1985), who stated that application of low level of $\mathrm{N}\left(56 \mathrm{~kg} \mathrm{~N} \mathrm{ha}^{-1}\right)$ was inadequate for marketable curd production, since most of the produced curds were extremely loose and unusable. The increase in total produced cauliflower yield might be due to the mode of the increment in the vegetative growth and dry matter contents of the growing plant organs (Tables 4 and 5) which in turn, increased the total and marketable yield.

\section{(B) Effects of chicken manure:}

Table (8) showed significant linear increase due to chicken manure application up to $15 \mathrm{~m}^{3}$ fad. ${ }^{-1}$ in the total and marketable yield during both seasons of experiments. High chicken manure rate $\left(15 \mathrm{~m}^{3}\right.$ fad. $\left.^{-1}\right)$ recorded maximum total yield $(40.997,39.594$ Ton fad. $\left.{ }^{1}\right)$ and marketable yield (39.477, 38.128 Ton fad. $\left.^{-1}\right)$ in both seasons, respectively. These values are corresponding for $(48.26 \%, 63.33 \%)$ and $(65.98 \%$, $86.12 \%$ ) increase in both total and marketable yield compared with control treatment (without chicken manure addition) in the first and second seasons, in succession. At the same time, the organic $\mathrm{N}$ rate $\left(15 \mathrm{~m}^{3}\right.$ fad. ${ }^{-1}$ ) recorded the minimum non-marketable yield $\left(1.472,1.427\right.$ Ton fad. $\left.^{-1}\right)$ in the first and second seasons, respectively. The enhancement effect of such application of chicken manure could be related to the fact that, chicken manure is considered a rich source of $\mathrm{N}$ and provides slow release of nutrients during the growth season (Abou El-Magd et al., 2006, Hasanin, 2007 and Shaheen et al., 2007). On the other side, organic manures can improve soil aggregation, soil aeration, increasing water holding capacity, encouragement of rhizosphere and non-rhizosphere microbial activity and offers good environmental conditions for the root system of growing cruciferous plants (Smith and Hadley, 1988 and Abou El-Magd et al., 2006). These conditions creates better nutrients absorption and favors the growth and development of root system which in turn, reflects vigorous vegetative growth, better photosynthetic activity and more dry matter accumulation (Abou ElMagd et al., 2006).

\section{(C) Collaborative effects of inorganic and organic $\mathbf{N}$ fertilizers:}

The obtained results revealed that the collaborative treatments significantly affected both total and marketable yield as well as non-marketable yield in both seasons (Table 8). It could be concluded that the maximum total and marketable yield of cauliflower plants was recorded by combined effect of the highest levels of inorganic and organic $\mathrm{N}$ fertilizer $(120 \mathrm{~kg} \mathrm{~N}$ fad. $^{-1}$ as $\mathrm{NH}_{4} \mathrm{NO}_{3}+15 \mathrm{~m}^{3}$ fad. $^{-1}$ as chicken manure) followed by the medium level of inorganic $\mathrm{N}$ with the highest rate of chicken manure $\left(80 \mathrm{~kg} \mathrm{~N}\right.$ fad. ${ }^{-1} \mathrm{NH}_{4} \mathrm{NO}_{3}$ $+15 \mathrm{~m}^{3}$ fad. $^{-1}$, chicken manure) in the two seasons. However, the highest values of non-marketable yield were recorded with all unfertilized treatments under any level of inorganic $\mathrm{N}$ fertilizer (Table 8).

The medium and high inorganic $\mathrm{N}$ levels (80 and $120 \mathrm{~kg} \mathrm{~N}$ fad. $^{-1}$, combined with the highest rate of chicken manure $\left(15 \mathrm{~m}^{3} \mathrm{~N}\right.$ fad. $\left.{ }^{-1}\right)$ significantly decreased inflorescence stalks length than control treatment in both seasons, which in turn can increase curds quality, namely compactness (Abdel-Razzak et al. 2008-a). This might be related to a limiting $\mathrm{N}$ supply; i.e., unfertilized treatments (zero inorganic and organic $\mathrm{N}$ levels) are associated with curd looseness. Such looseness of the curd can be regarded as the onset of bolting (Rather et al., 1999), accordingly, increased non-marketable yield under the present study conditions. 
Abdel-Razzak, H. S and A. B. El-Nasharty: Vegetative Growth and Yield Potential of Cauliflower (Brassica oleraceae var. botrytis, L.) ... 337

It can concluded that the favorable effects for such combinations between inorganic and organic $\mathrm{N}$ fertilization might be due to their beneficial and positive influences on the development of more adequate vegetative growth (Tables 4 and 5) which is rich in several essential nutrients (Tables 6 and 7); which in turn, should be reflected on the production of high yield with decreasing non-marketable one.

\section{CONCLUSION}

The apparent high demand of $\mathrm{N}$ required for growing and head production of "Amshiry" cultivar cauliflower under this study suggests that split application may be useful for increasing $\mathrm{N}$ use efficiency. It can confirm the findings of Welch et al., (1985) and Tyler and Lorenz, (1991), who found that splitting $\mathrm{N}$ applications are prerequisite in order to match $\mathrm{N}$ supply to crop needs and increased the yield of cauliflower. It is also clear that the better vegetative growth, maximum cauliflower yield and high concentrations of several important nutrients in leaves were obtained from plants supplied with the highest level and rate of inorganic and organic $\mathrm{N}$ fertilizer (120 $\mathrm{kg} \mathrm{N}$ fad..$^{-1}$ of $\mathrm{NH}_{4} \mathrm{NO}_{3}+15 \mathrm{~m}^{3}$ fad. ${ }^{-1}$; i.e., $72 \mathrm{~kg} \mathrm{~N}$ fad. ${ }^{-1}$ of chicken manure) followed by the medium inorganic $\mathrm{N}$ level and the highest rate of organic $\mathrm{N}\left(80 \mathrm{~kg} \mathrm{~N}\right.$ fad. ${ }^{-1}$, $\mathrm{NH}_{4} \mathrm{NO}_{3}+15 \mathrm{~m}^{3}$ fad. ${ }^{-1}$; i.e., $72 \mathrm{~kg} \mathrm{~N}$ fad. ${ }^{-1}$ of chicken manure) which were superior to the other treatment in cauliflower "Amshiry" cultivar. Moreover, the use of chicken manure in cauliflower production fields can be considered as an alternative choice to decrease the application of high quantities of inorganic $\mathrm{N}$ fertilizer, and consequently can reduce the total cost of cauliflower production and the unfavorable effects on the environment under this study region conditions.

\section{REFERENCES}

Abdel-Razzak, H. S., T. H. Gamel and A. B. El-Nasharty. 2008-a. Efficiency of inorganic and organic nitrogen fertilization on cauliflower (Brassica oleraceae var. botrytis, L.) curds quality. Alex. Sci. Exch. J. 29(4): 283297.

Abdel-Razzak, H. S., T. H. Solieman and T. H. Gamel. 2008b. Influences of mineral nitrogen fertilizer sources and levels on vegetative growth, yield, curd quality and nutritional value of cauliflower (Brassica oleraceae var. botrytis, L.). Alex. J. Agric. Res. 53(2): 71-84.

Abou El-Magd, M. M., A. M. El-Bassiony and Z. F. Fawzy. 2006. Effect of organic manure with or without chemical fertilizers on growth, yield and quality of some varieties of broccoli plants. J. Appl. Sci. Res. 2(10): 791-798.

Badawy, A. S.; M. H. Hosseny; H. E. Mohamed and E. A. Fouad. 2007. Effect of organic and inorganic fertilization on growth, yield and quality of two garlic cultivars. Assiut J. Agri. Sci. 38(3): 29-44.
Batal, K. M., D. M. Granberry and B. G. Mullinix, Jr. 1997. Nitrogen, magnesium, and boron applications affect cauliflower yield, curd mass, and hollow stem disorder. Hort. Sci. 32(1): 75-78.

Bowen, P. A., B. J. Zebarth and P. M. A. Toivonen. 1999. Dynamics of nitrogen and dry-matter partitioning and accumulation in broccoli (Brassica oleraceae var. italica) in relation to extractable soil inorganic nitrogen. Can. J. Plant Sci. 79: 277-286.

Chapman, H. D. and P. F. Pratt. 1978. Methods of Analysis for Soils, Plants and Waters. Division of Agric. Sci., Univ. California, Berkeley, USA. 309 p.

Co-State Software. 2004. User's manual version. Cohort Tusson, Arizona, USA.

Csizinszky, A. A. 1996. Optimum planting time, plant spacing, and nitrogen and potassium rates to maximize yield of green cauliflower. Hort. Sci. 31(6): 930-933.

Dufault, R. J. and L. Waters, Jr. 1985. Interaction of nitrogen fertility and plant populations on transplanted broccoli and cauliflower yields. Hort. Sci. 20(1): 127-128.

Fattah-Allah, M. A.; R. M. Khalil; N. M. Malash and S. A. Midan. 1997. Response of some promising pepper genotypes to farmyard manure and nitrogen fertilization. b. Yield, yield components and fruit quality. Menofiya J. Agric. Res. 22(2): 459-491.

Farag, I. A.; M. A. Farghali; E. F. Refai and G. I. Shalaby. 1994. Responses of two cultivars of cauliflower to nitrogen rates, boron and molybdenum. Assiut J. Agric. Sci., 25(5): 221-233.

Farrag, A. M., J. F. Mishriky and A. M. El-Nagar. 2000. Effect of drip irrigation levels and nitrogen rates on growth and yield of cauliflower plants \& salts accumulation in soil. J. Agric. Sci. Mansoura Univ., 25(5): 2855-2875.

Giardini, L; F. Pimpini; M. Borin and G. Gianquinto. 1992. Effects of poultry manure and mineral fertilizers on the yield of crops. J. Agric. Sci. Camb., 118: 207-213.

Hasanin, N. M. 2007. A comparison between the effect of compost and chicken manure fertilizers on productivity and fruit quality of two strawberry cultivars grown under transparent polyethylene low tunnels. Minufiya J. Agric. Res. 32(2): 419-440.

Helmy, A. M. and M. F. Ramadan. 2008. Physiological and chemical response of sunflower to some organic nitrogen sources and conventional nitrogen fertilizers under sandy soil conditions. Zagazig J. Agric. Res., 35(2): 315-341.

Isamu, B. 1972. Official methods of analysis of fertilizers. Publish National Institute of Agricultural Science, Ministry of Agriculture and Forestry, Nishigahara, KilaKu, Tokyo, Japan. $96 \mathrm{p}$.

Jones, J. B., Wolf, B. and H. A. Mills. 1991. Plant Analysis Handbook: A practical sampling, preparation, analysis and interpretation guide. Micro-Macro Publishing, Inc., Georgia, USA. 213 p.

Kubota, A.; T. L. Thompson; T. A. Doerge and R. E. Godin. 1996. A petiole sap nitrate test for cauliflower. Hort. Sci. 31(6): 934-937. 
Kumar, P.; A. S. Halepyati; B. T. Pujari and B. K. Desai. 2007. Effect of integrated nutrient management on productivity, nutrient uptake and economics of maize (Zea mays L.) under rainfed condition. Karnataka J. Agric. Sci., 20(3): 462-465.

Markovic, V. and M. Djurovka. 1990. The effect of mineral nutrition on the yield and quality of cauliflower. Acta Hort. 267: 101-109.

Marschner, H. 1994. Mineral Nutrition in Higher Plants. Academic Press, Harcout Brace. Jovanovish Publisher, pp. 6-74.

Moussa, A. G.; A. El-Shal; A. Abdel-Razik and H. AbdelRazzak. 1993. Efficiency of organic and mineral fertilization on yielding of lettuce (Lactuca sativa L.). Zagazig J. Agric. Res. 20(5): 1583-1592.

Nothmann, J. 1976. Morphology of head formation of cos lettuce (Lactuca sativa L. cv. Romana). I- The process of hearting. Ann. Bot. 40(169): 1067-1072.

Rather, K.; M. Schenk; A. Everaarts and S. Vethman. 1999. Response of yield and quality of cauliflower varieties (Brassica oleracea var. botrytis) to nitrogen supply. J. Hort. Sci. \& Biotechnol. 74(5): 658-664.

Rizk, T. Y., A. A. Abdel Haleem and I. Kh. Mohamed. 2006. Effect of organic, bio and mineral fertilization treatments on yield, yield components and chemical contents of seeds of faba bean (Vicia faba L). Egypt. J. Agric. Res., 84(1): 153-163.

Sanchez, C. A.; R. L. Roth; B. R. Gardner and H. Ayer. 1996. Economic responses of broccoli and cauliflower to water and nitrogen in the desert. Hort. Sci. 31(2): 201-205.

Sanderson, K. R. and J. A. Ivany. 1999. Cole crop yield response to reduce nitrogen rates. Can. J. Plant Sci. 79: 149-151.
Shaheen, A. M., F. A. Rizk and Z. F. Fawzy. 2007. Yield and some chemical constituents of onion as influenced by organic manures. J. Agric. Sci. Mansoura Univ. 32(10): 8513-8523.

Sherif, F. K. and A. A. M. El-Naggar. 2005. Effect of biofertilizer application to manure on calla lily (Zantedeschia aethiopica L. spring) production and nutrients release in sandy soil. Alex. J. Agric. Res., 50(1): 181-192.

Smith, S. R. and P. Hadley. 1988. A comparison of the effects of organic and inorganic nitrogen fertilizers on the growth response of summer cabbage (Brassica oleraceae var. capitata cv. Hispi F1). J. Hort. Sci., 63(4): 615-620.

Splittstoesser, W. E. 1990. Vegetable Growing Handbook. Organic and traditional method. An avi Book. Van Nostrand Reinhold. New York. 362 p.

Steel, R. G. D. and J. H. Torrie. 1980. Procedures of statistics ( $2^{\text {nd }}$ Edition), McGraw Hill Book Co., Inc. New York, USA.

Thompson, T. L., T. A. Doerge and R. E. Godin. 2000. Nitrogen and water interaction in subsurface Dripirrigated cauliflower: I. plant response. Soil Sci. Soc. Am. J. 64: 406-411.

Tyler, K. B. and O. A. Lorenz. 1991. Fertilizer guide for California vegetable crops. Department of Vegetable Crops, Univ. of California, Davis.

Welch, N. C.; K. B. Tyler; D. Ririe, and F. E. Broadbent. 1985. Nitrogen uptake by cauliflower. Calif. Agric. Nov. Dec. 21-22.

Wurr, D. C. E.; R. H. Kay; E. J. Allen and J. C. Patel. 1981. Studies of the growth and development of winter-heading cauliflowers. J. Agric. Sci. Camb. 97: 409-419.

Yildirim, E. and I. Guvenc. 2005. Intercropping based on cauliflower: more productive, profitable and highly sustainable. Europ. J. Agron. 22: 11-18. 
Abdel-Razzak, H. S and A. B. El-Nasharty: Vegetative Growth and Yield Potential of Cauliflower (Brassica oleraceae var. botrytis, L.) ... 339

\section{الملخص العربي}

\section{تأثر النمو الخضري والجها الخصولي لنبات القنبيط بالسماد النيتروجيني المعدلي والعضوي}

$$
\text { هشام عبد الرزاق صالح، عادل بدر النشرتي }
$$

تر كيزات كل من العناصر الكبرى والصغرى في أوراق القنبيط.

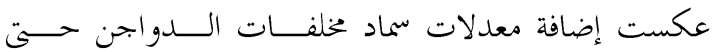
مامَّ/ فدان ( VT كجم ن/ فدان) زيادة معنوية في صفات النمو

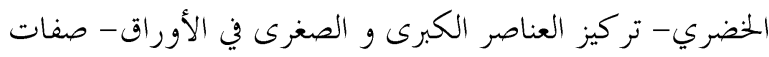
الجهد المصصولي (المصول الكلي والمصول القابل للتسويق) لنبات القنبيط خلال موسمي الدراسة.

تشير نتائج التفاعل بين كل من مستويات السماد النيتروجيني

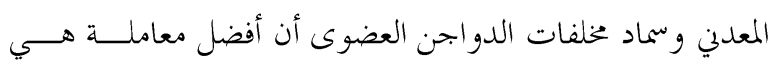

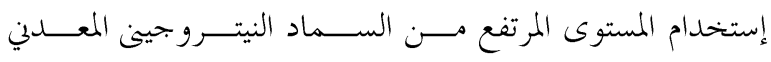

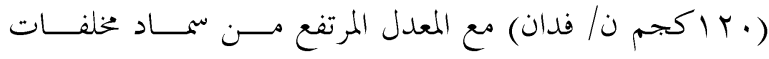

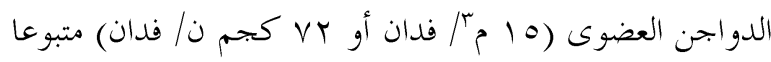

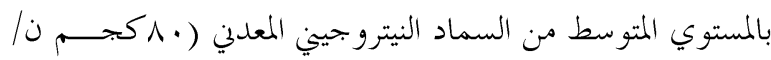

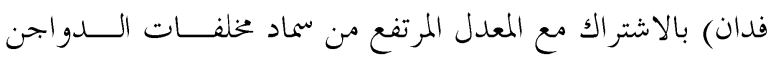

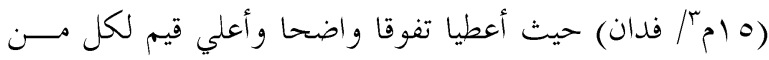

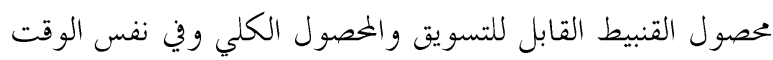
قللا من محصول القنبيط غير القابل للتسويق. يمكن التوصية من هذه الدراسة أنه بإستخدام سماد مخلفــات

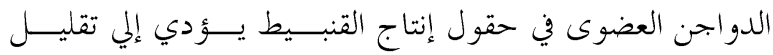

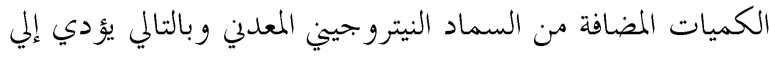
تقليل تكاليف إنتاج محصول القنبيط و كذلك يقلل من التــأثيرات السلبية علي البيئة تحت ظروف منطقة الدراسة.
أجريت تجربتين حقليتين في مططة البحوث الزراعية التابعسـة

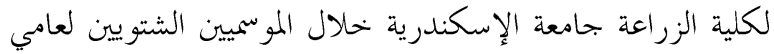

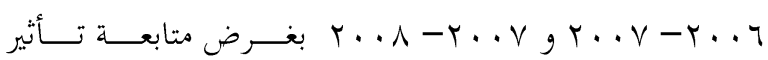
إستخدام مستويات مختلفة من السماد النيتروجيني المعلدي (صفر-

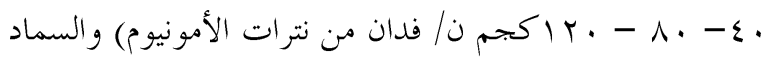

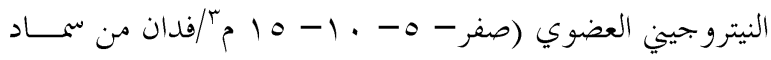
مخلفات الدواجن) وكذلك التأثير المشترك لهما على صفات النمو الخضري والمكونات الكيميائية للأوراق. بالإضافة إلي تحديد كل

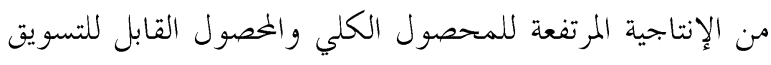
وقلة الإنتاجية من محصول القنبيط غير القابل للتسويق في الصنف

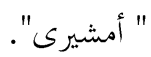

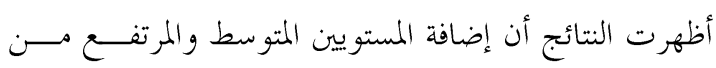

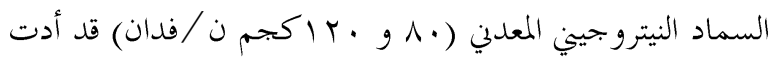
إلي حدوث زيادة معنوية في معظم صفات النمو الخضري مثــلـل

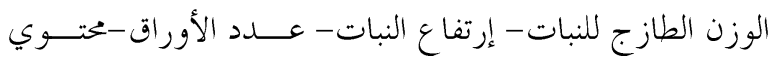

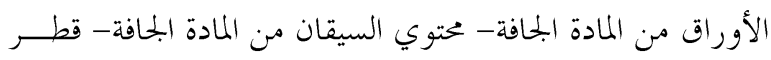

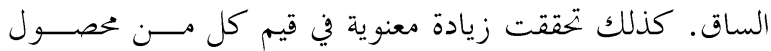

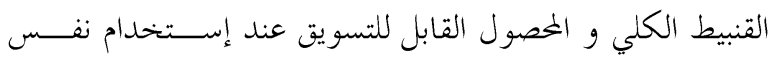

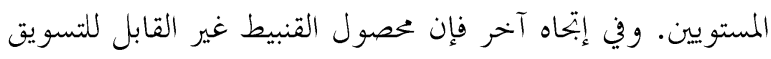

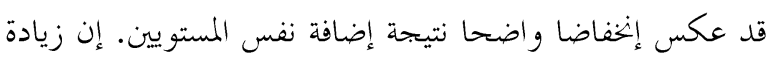

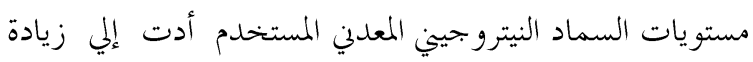

